\title{
Rehabilitation of a patient with atrophic ridges using gothic arch tracing and nonpressure impression: a case report
}

\author{
Shin-Yeop Lee, Jung-Hyun Yu* \\ Department of Prosthetic Dentistry, Veterans Health Service Medical Center, Seoul, Republic of Korea
}

Flabby ridges adversely affect the stability of complete dentures. For the management it is suggested that soft tissues reconditioned before making definitive dentures, and modified impression techniques used for the flabby ridges. Also, correct record of centric relation is important in complete dentures. This case of 67-year-old edentulous female patient had atrophied ridges on the mandible and the flabby ridge on the maxilla. Treatment dentures were fabricated using gothic arch tracing method and tissue conditioner. Definitive dentures were made using window opening impression technique, the gothic arch tracing method, and lingualized occlusion. The patient was satisfied with the function and esthetic quality of the new prostheses. (J Dent Rehabil Appl Sci 2018;34(3):232-38)

Key words: edentulous mouth; complete denture; gothic arch tracing; flabby ridge; nonpressure impression

\section{서론}

총의치 제작 이후 첨상이나 개상 등의 지속적인 관리 및 보상이 되지 않는 환자에서 잔존치조제의 흡수로 인 해 의치의 부적합이 나타나게 되며, 이런 불안정한 의 치로 인해 가동성 치조제(flabby ridge)나 치은열성비대 (epulis fissuratum)와 같은 구강 내 증상이 발생하게 된 다. 가동성 치조제는 골이 섬유조직으로 개치된 것으로, 무치악 치조제의 상하악 전방부에서 흔히 나타난다. 치 은열성비대는 열구 상피가 증식성 조직 회복 반응을 하 여 발생하며, 상악 순측 잔존 치조제에서 가장 흔하게 일 어난다. ${ }^{1}$ 새로운 총의치를 제작하기 전에 의치 지지부와 치조제 관계를 개선하는 치료가 선행되어야 하며, ${ }^{2}$ 치료 에는 비외과적인 방법과 외과적인 방법이 있다. 비외과적 인 방법으로는 조직조정재를 이용하여 조직을 회복시키 는 방법이 있고, 특히 가동성 치조제를 가졌으나 환자의

*Correspondence to: Jung-Hyun Yu Department of Prosthetic Dentistry, Veterans Health Service Medical Center, 53, Jinhwang-doro 61-gil, Gangdong-gu, Seoul, 05368, Republic of Korea Tel: +82-2-2225-3956, Fax: +82-2-2225-3929, E-mail: yjhdream@hanmail.net Received: June 14, 2018/Last Revision: July 9, 2018/Accepted: July 27, 2018
건강이나 개인적인 성향 등으로 외과적 수술을 적용할 수 없을 경우, 조직의 변형을 최소화 하는 인상방법을 이 용하여 의치의 적절한 지지를 얻을 수 있다. ${ }^{3}$

유치악 환자에서와 같이 무치악 환자의 총의치 제작 시에도 적절한 교합에 대한 원칙이 적용되는데, 총의치 의 안정을 위해서는 중심교합이 중심위와 조화를 이루도 록 해야 하며, 중심위의 정확한 기록이 중요하다. ${ }^{4}$ 중심 위를 결정하는 방법은 교합간 기록 또는 고딕 아치 기록 (gothic arch tracing)이 있는데, 고딕 아치 기록은 상악에 부착된 묘기침이 대합되는 하악에 위치한 묘기판에 닿도 록 해서 수평면에서의 전방 및 좌우 측방의 하악 운동을 기록하는 방법이다.

총의치의 교합 양식과 치아 배열 방식은 교합력을 조 절하는 중요한 요소 중 하나로, 특히 심하게 흡수된 하악 잔존치조제를 가진 환자에서 총의치 교합양식은 신중하 게 결정되어야 한다. 상악 구치의 설측 교두를 하악 구치 
의 중심와와 접촉시킴으로써 교합력이 하악 치조정에 가 깝게 작용되게 하는 교합양식을 설측 교두 교합(lingualized occlusion)이라고 하며, 설측 교두 교합은 교합력을 설측화 시킬 수 있어 하악 총의치를 안정화 시킬 수 있다 는 장점이 있다. ${ }^{5}$

\section{증례보고}

본 증례의 환자는 67 세의 여환으로 하악 우측 구치부 의 잔존치근의 발거 이후 보철 수복을 위하여 본 과에 의 뢰되었다(Fig. 1). 환자는 상, 하악 완전무치악 상태로 30 년 전에 제작한 가철성 국소의치를 총의치로 수리하여 사용하고 있었으며, 수리한 구 의치에서는 부적절한 변 연 연장과 불량한 적합도, 그리고 불안정한 교합이 관찰 되었다. 상악 의치에서는 여러 번 첨상된 재료가 일부 탈 락된 상태였고, 하악 의치는 구후융기까지 연장되지 않 은 짧은 의치상연을 가지며, 상, 하악 의치 모두에서 심한 인공치의 마모가 관찰되었다(Fig. 2). 임상적으로 환자의 구내 관찰 시, 상악 우측 전치부의 가동성 치조제와 치은 열성비대가 보이고 구개부에서는 구 의치로 인한 압흔이
관찰되었다. 하악에서는 전치부와 구치부 모두에서 심한 치조골 흡수 및 위축된 잔존치조제가 관찰되었다(Fig. 3). 의치 지지조직의 회복과 구 의치로 인한 불안정한 하악 운동위의 개선을 위하여 치료용 의치의 제작이 먼저 결 정되었다. 알지네이트로 인상 채득 후 구 의치로 인한 불 안정한 하악위를 피하고 정확한 중심위의 기록을 위하여 악간관계 결정 단계에서 고딕 아치 기록을 사용하여 수 평 악간관계를 기록하였다. 반복된 지시와 시도를 통해

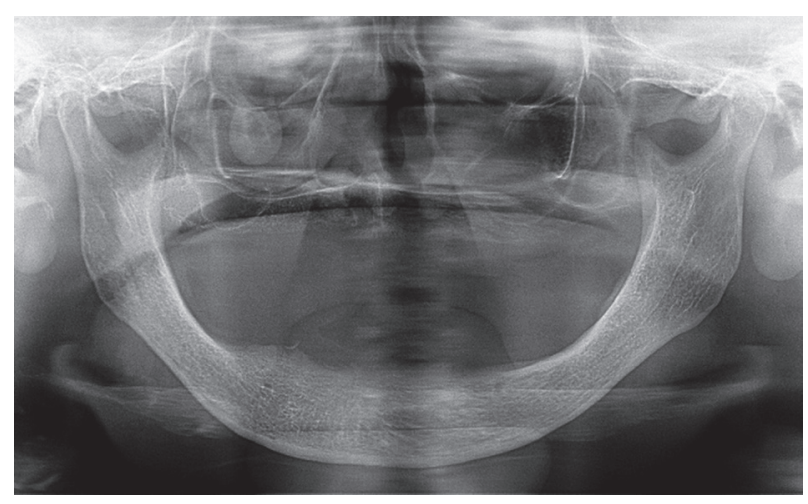

Fig. 1. Initial panoramic radiograph.
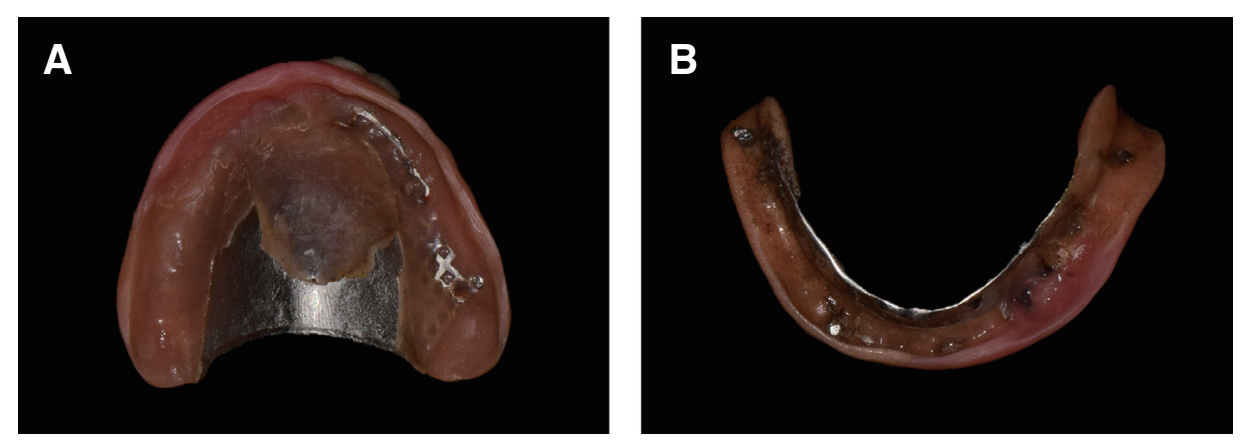

Fig. 2. Pre-existing old dentures. (A) Maxillary denture with partial dislodgement of a relining material, (B) Mandibular denture with the short posterior border.
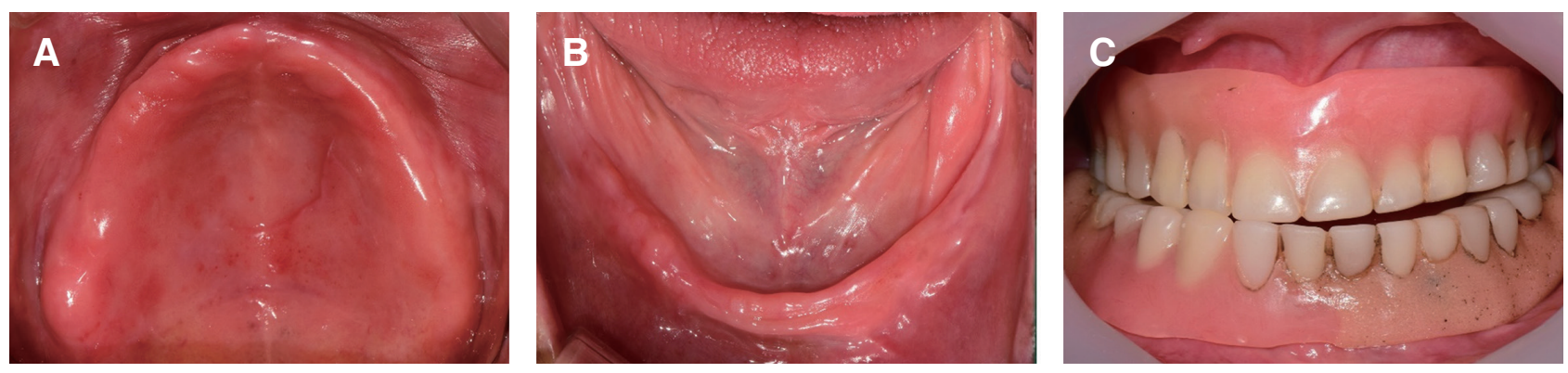

Fig. 3. Initial intraoral photographs. (A) Maxilla, flabby tissue and epulis fissuratum were observed at right anterior region, (B) Mandible with atrophied ridges, (C) Intraoral Photograph with old dentures showing unstable occlusion. 
양호한 하악 운동위가 그려지고 정점에서 tapping point 가 나타나 그 때의 위치를 비닐실리콘(Vinyl Polysiloxane) 교합인기재(O-Bite, DMG, Hamburg, Germany)로 기록하였다(Fig. 4). 치료용 의치가 제작된 후 일주일에 2회씩 4주간 조직조정재(Tissue Conditioner II, Shofu INC, Tokyo, Japan)를 이장하여 조직을 회복하였다(Fig. $5)$.

4주간의 치료용 의치 사용 후 안정된 하악위가 관찰되 었으며 가동성 치조제가 완전히 없어지지는 않았으나 환 자가 수술을 원치 않아 외과적 절제 없이 최종의치를 제 작하기로 결정하였다. 최종의치의 제작을 위해서 인상채 득하여 진단모형을 제작 후 개인트레이를 만들었고, 통 법에 따라 모델링콤파운드로 변연을 형성하였다. 상악에 서 변연 형성 이후 가동성 치조제 부위의 개인트레이에 창(window)을 내어 친수성 비닐실리콘 인상재(Exadenture, GC, Tokyo, Japan)로 인상채득한 후에 가동성 치조 제 부위에 다시 친수성 비닐실리콘 인상재(Imprint ${ }^{\mathrm{TM}} \mathrm{II}$ Garant ${ }^{\mathrm{TM}}$ Light Body, 3M ESPE, St. Paul, USA)를 뿌리

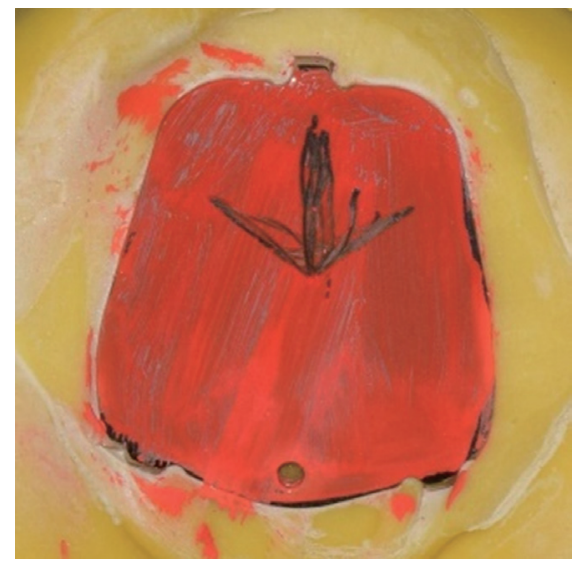

Fig. 4. Gothic arch tracing for treatment dentures.
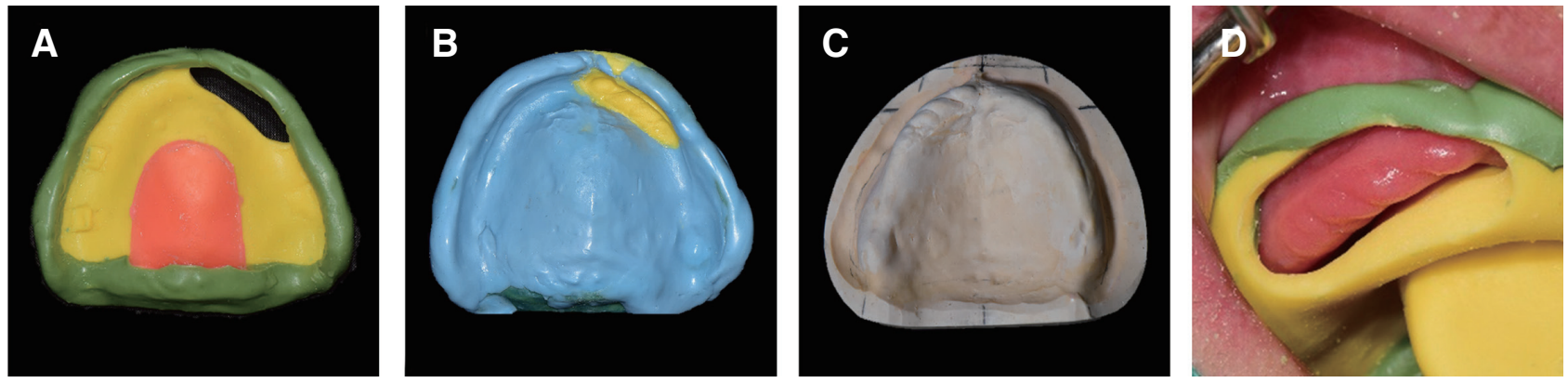

Fig. 6. Maxillary impression. (A) Border molding using modeling compound, (B) Impression, (C) Master cast, (D) Window formation on flabby ridge. 

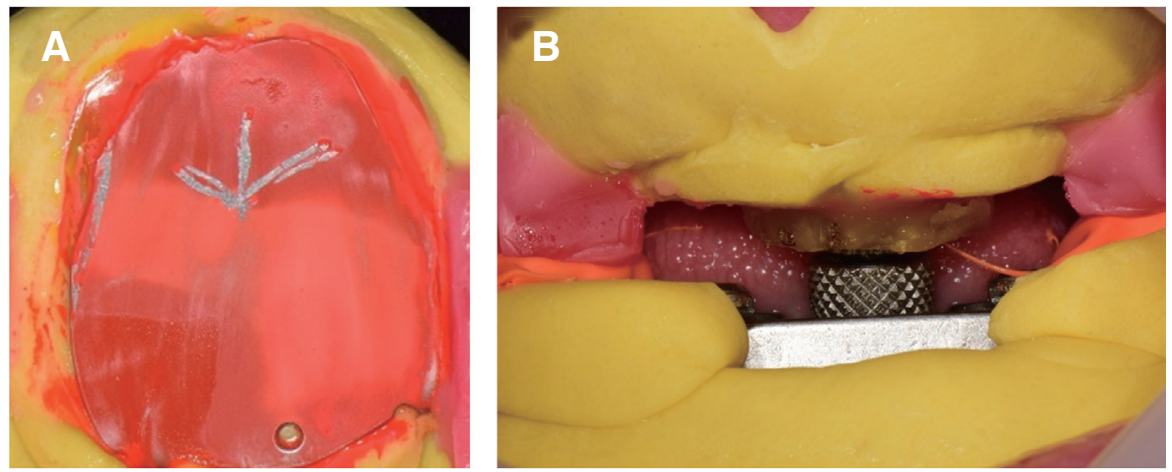

Fig. 7. Gothic arch tracing for definitive dentures $(A)$ and bite registration (B).
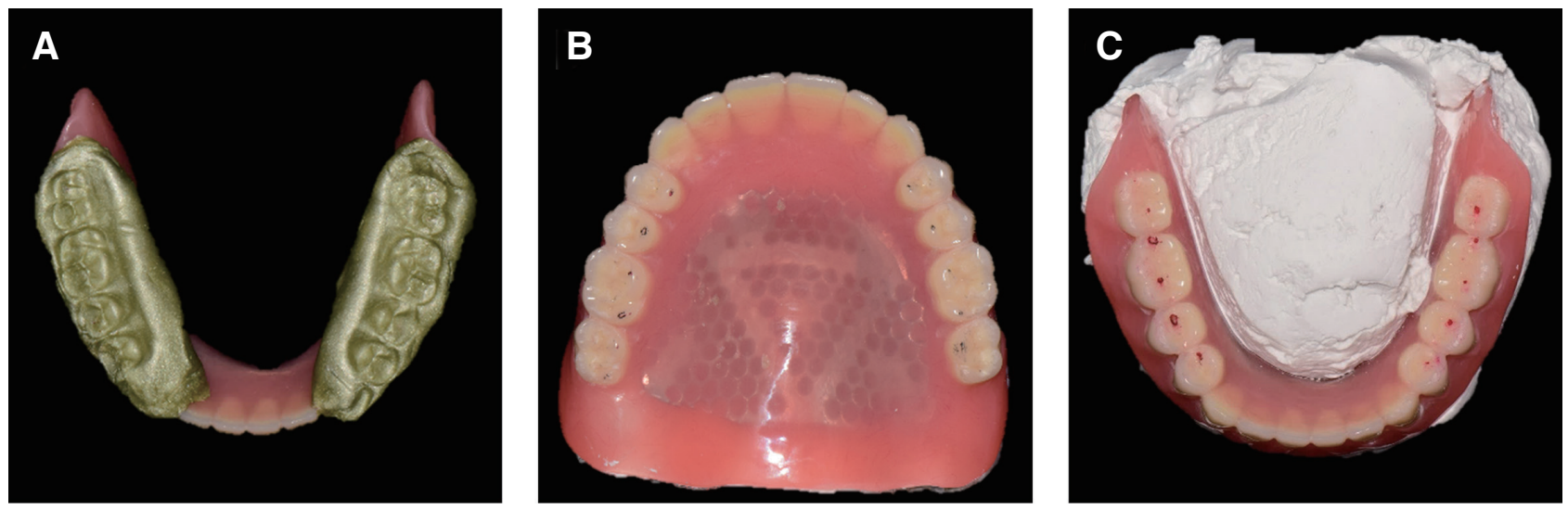

Fig. 8. Bite registration using alu-wax for clinical remounting $(A)$, and lingualized occlusion (B, C).
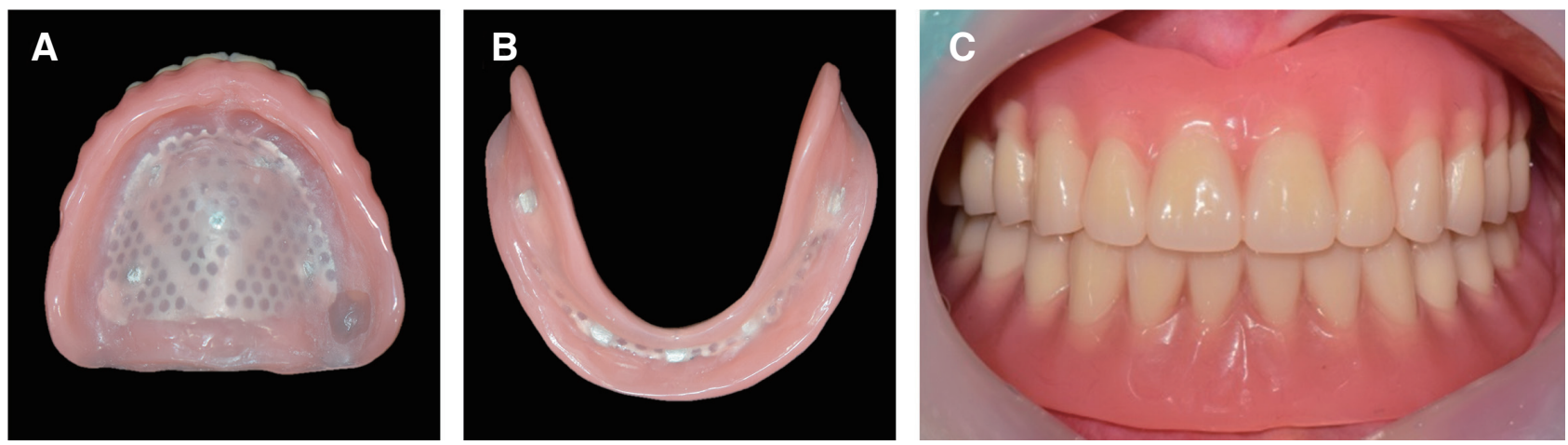

Fig. 9. Definitive dentures, (A) polished surface of maxillary denture, (B) polished surface of mandibular denture, (C) Intraoral view with definitive dentures.

부착하여 설측 교두 교합으로 교합조정 이후 환자에게 의치를 장착하였다(Fig. 8).

구강 내 장착한 이후 의치는 만족할만한 유지력과 안 정성을 나타냈으며, 환자도 기능 및 심미적으로 매우 만 족하였다(Fig. 9).

\section{고찰}

부적합한 의치를 오랫동안 사용하는 환자에게서 건강 한 치조제가 유지되기는 어려우며, 부적합한 의치는 하 방의 연조직을 변형시키고 특정 부위에 강한 압력을 가 
하여 하방의 지지골을 파괴하는 부적절한 요소로 작용할 수 있다. ${ }^{2}$ 또한 가동성 치조제는 쉽게 변위되어 의치의 기 능시 유지력과 안정성을 감소시키므로, ${ }^{6}$ 변형된 연조직들 은 새로운 총의치 제작 전에 회복시켜야 한다. 이러한 가 동성 치조제의 문제를 비외과적인 방법으로 극복하기 위 한 다양한 변형된 인상법이 소개되었는데, Watson ${ }^{7}$ 은 가 동성 치조제가 존재하는 부위에 창을 낸 개인트레이를 제작하는 인상 방법을 소개하였고, $\mathrm{Comut}^{8}$ 은 Watson의 방법과 유사하나 비닐실리콘 인상재를 이용하여 한번에 인상을 채득하는 방법을 묘사하였다. 본 증례에서는 창 을 형성하여 가동성 치조제 부위를 무압인상 채득하는 방식으로 조직의 변형을 최소화하여 안정된 의치를 제작 하였다.

완전 무치악 환자는 하악 운동의 조절이 감소되며 주 로 전방으로 변위된 하악위가 관찰된다. 이러한 환자의 보철적 수복을 위해서는, 인공치의 중심교합이 가장 반 복적인 하악의 폐구위인 중심위와 일치하도록 하여야 한 다. 최초의 'graphic recordings'는 1866년 Balkwill의 하 악 운동에 관한 연구에 근거하였다. 1897년 Hesse에 의 해 가장 처음으로 알려진 "needle point tracing" 방법은 이후 1910년 Gysi에 의해 발전되고 대중화되었다. Gysi 는 왁스와 컴파운드를 이용한 교합간 기록은 25 도의 오 차가 있는 반면에 그의 방법은 5 도 정도의 오차만 있다 고 주장하였다. ${ }^{4}$ 고딕 아치 기록과 같은 중심위를 기록하 기 위한 'graphic recordings'는 여러 연구를 통하여 찬사 와 비판을 받았는데, Myers'는 치과의사가 유도하는 중 심위가 고딕 아치 기록보다 더 재현 가능하다는 주장에 는 근거가 없다고 하였으며, Howell ${ }^{10}$ 은 무치악 환자에 서 6개의 수평 악간 관계 기록법들을 비교하여 환자가 직 접 움직이는 고딕 아치 기록이 가장 일관된 결과를 나타 낸다고 발표하였다. 반면에 Block ${ }^{11}$ 은 sore spot의 존재 가 eccentric tracing을 야기할 수 있다는 점을 지적하였 고, $\mathrm{Payne}^{12}$ 은 지나치게 환자의 협조도가 많이 필요하기 때문에 부정확할 수 있다고 하였다.

고딕 아치 기록 채득 과정에서 정확한 중심위의 재현은 묘기침의 위치와 각도, 그리고 묘기판의 기울기에 크게 영향을 받고, 환자의 폐구압의 크기에 의해서도 영향을 받기 때문에 최소한의 폐구압으로 시행되어야 하며 교합 력은 중심화되고 고르게 분산되어야 한다. ${ }^{13}$ 본 증례에서 는 수직고경을 먼저 결정하고 안궁이전하여 장치를 제작 함으로써 전술한 변수들의 영향을 최소화하였으며, 가 동성 치조제의 변형을 최소화하는 인상법으로 제작된 기
록상으로 고딕 아치 기록을 사용할 때의 안정성을 충분 히 확보할 수 있었다. 고딕 아치 기록을 사용할 때는 이에 대한 환자의 교육과 협조도가 요구되며, 적절하게 시행 된 고딕 아치 기록은 정확한 중심위를 채득하는 좋은 방 법이 된다.

총의치 환자에서 구치부 교합양식은 양측성 균형교합 과 설측 교두 교합이 대표적이지만 양측성 균형교합을 임상적으로 완전하게 형성해 주기에는 어렵고 많은 시간 이 걸린다. ${ }^{14}$ 이에 따라 임상적인 환자의 요구들을 만족 하면서 조금 더 단순한 교합양식이 필요하게 되었는데, 설측 교두 교합은 치아배열과 교합조정이 양측성 균형교 합보다 더 쉽다는 장점이 있다. Matsumaru ${ }^{15}$ 는 잔존치조 제가 심하게 흡수된 환자에서 설측 교두 교합으로 의치 를 제작하는 것이 의치 안정성 측면에서 좋은 교합양식 이라고 하였다.

\section{결론}

본 증례에서는 상악의 가동성 치조제 및 하악의 심하 게 흡수된 치조제를 가진 완전 무치악 환자에서 정확한 중심위의 기록을 위해 고딕 아치 기록을 이용하여 치료 용 의치를 제작 후 조직조정을 시행하였으며, 의치 제작 을 위해 가동성 치조제의 움직임을 최소로 하는 변형된 방법으로 인상을 채득하고, 다시 한 번 고딕 아치 기록을 시행하여 정확한 중심위를 기록 후, 설측 교두 교합을 적 용하여 새 의치를 제작함으로써 환자에게서 높은 만족도 를 얻을 수 있었다.

\section{ORCID}

Shin-Yeop Lee https://orcid.org/0000-0001-6457-4212

Jung-Hyun Yu https://orcid.org/0000-0002-1527-5926

\section{References}

1. Carlsson GE. Clinical morbidity and sequelae of treatment with complete dentures. J Prosthet Dent 1998;79:17-23.

2. Lytle RB. Complete denture construction based on a study of the deformation of the underlying soft tissue. J Prosthet Dent 1959;9:539-51.

3. Lynch CD, Allen PF. Management of the flabby ridge: using contemporary materials to solve an old 
problem. Br Dent J 2006;200:258-61.

4. Myers ML. Centric relation records-historical review. J Prosthet Dent 1982;47:141-5.

5. Phoenix RD, Engelmeier RL. Lingualized occlusion revisited. J Prosthet Dent 2010;104:342-6.

6. Barone JV. Physiologic complete denture impressions. J Prosthet Dent 1963;13:800-9.

7. Watson RM. Impression technique for maxillary fibrous ridge. Br Dent J 1970;128:552.

8. Comut A, Anrawis M. Maxillary definitive impression of excessively movable tissue with a single material. J Prosthet Dent 2015;114:616-8.

9. Myers M, Dziejma R, Goldberg J, Ross R, Sharry J. Relation of Gothic arch apex to dentist-assisted centric relation. J Prosthet Dent 1980;44:78-81.

10. Howell RA. A clinical study of horizontal jaw rela- tionships in edentulous patients. J Dent 1981;9:31827.

11. Block LS. Common factors in complete denture prosthetics. J Prosthet Dent 1953;3:736-46.

12. Granger ER. Centric relation. J Prosthet Dent 1952;2:160-71.

13. Yurkstas AA, Kapur KK. Factors Influencing centric relation records in edentulous mouth. 1964. J Prosthet Dent 2005;93:305-10.

14. Parr GR, Ivanhoe JR. Lingualized occlusion. An occlusion for all reasons. Dent Clin North Am 1996;40:103-12.

15. Matsumaru Y. Influence of mandibular residual ridge resorption on objective masticatory measures of lingualized and fully bilateral balanced denture articulation. J Prosthodont Res 2010;54:112-8. 


\section{심하게 흡수된 치조제를 가진 환자에서 고딕 아치 기록과 무압 인상을 이용한 총의치 수복: 증례보고}

\section{이신엽, 유정현*}

한국보훈복지공단 중앙보훈병원 치과보철과

가동성 조직은 총의치의 안정성을 감소시키므로, 최종의치의 제작 전에 조직의 상태를 개선시킨 후 적합하게 수정된 인 상 방법을 사용하여야 하며, 적절한 중심위를 채득해야 한다. 본 증례는 상악의 가동성 조직과 하악 치조제의 심한 흡수 를 보이는 67 세의 무치악 여자 환자로, 고딕 아치 기록을 이용하여 치료용 의치를 제작한 뒤 조직조정을 시행하였다. 최 종의치는 window opening 인상채득법과 고딕 아치 기록, 그리고 설측 교두 교합을 이용하여 제작하였고, 심미적 및 기능 적으로 만족스러운 결과를 얻었기에 이를 보고하는 바이다.

(구강회복응용과학지 2018;34(3):232-38)

주요어: 무치악; 총의치; 고딕 아치 기록; 가동성 치조제; 무압인상 